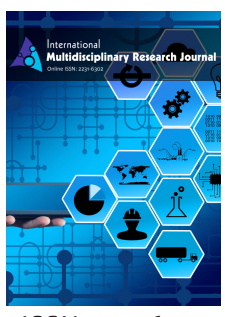

ISSN: $2231-6302$

Received: November 28, 2018 Accepted: February 17, 2019

Published: February 21, 2019

*Corresponding Author:

Zellagui

Email: rahima.zellagi@univ-

usto.dz,

rahima32@hotmail.fr,

r.zellagui@crti.dz

\section{Effect of zinc/cadmium proportion in CdS layers deposited by CBD method}

\author{
R. Zellagui ${ }^{1,2 *}$, H. Dehdouh², F. boufelgha², A. Boughelout ${ }^{2}$, T. Sahraoui', \\ D. Chaumont ${ }^{3}$, M. Adnane ${ }^{1}$
}

\author{
'Laboratory of Electron Microscopy and Materials Sciences, Université des Science et des Technologies d' Oran, \\ P.O. Box 1505 El-M'naouer, 31000 Oran, Algérie \\ ${ }^{2}$ Research Center in Industrial Technologies CRTI, P.O.Box 64, Cheraga 16014, Algiers, Algeria \\ ${ }^{3}$ Laboratoire Interdisciplinaire Carnot de Bourgogne, University of Bourgogne France Comté, Dijon, France
}

\begin{abstract}
Cadmium poisoning and the cost of panel recovery which is very expensive and difficult in the buffer layers of CdS in solar cell, for these two drawbacks, we do a search on the effect of proportion of zinc/cadmium in the properties layers of CdS. For this, our studies study the properties of $\mathrm{Cd}_{\mathrm{x}} \mathrm{Zn}_{1-\mathrm{x}} \mathrm{S}$ layers deposited by chemical bath (CBD). CdZnS thin films were synthesized by chemical bath deposition (CBD) with different deposition protocols to optimize deposition parameters such as temperature, deposition time, ion concentrations and $\mathrm{pH}$. The surface morphology, structural, optical and chemical properties of the CdZnS thin films were studied by SEM, XRD, Raman and UV-visible spectrophotometer. The transmittance is $80 \%$ in the visible region $300 \mathrm{~nm}-800 \mathrm{~nm}$; the crystalline structure is hexagonal and cubic, the grain size is between 9.95 to $25.82 \mathrm{~nm}$. It is observed that the transmittance and the shape change with the concentration of zinc in the solution; this result favors the application of these films in solar cells application.
\end{abstract}

KEYWORDS: CdZnS, chemical bath, SEM, Raman, Solar Cells, Thin Films

\# This article was presented in The $1^{\text {st }}$ International Conference of Computer Science and Renewable Energies (ICCSRE'2018), November 22-24, 2018 Ouarzazate, Morocco

\section{INTRODUCTION}

The first material used in photovoltaic is silicon. But the silicon is not the ideal material for solar cells based on thin films because of their high cost of the production and low absorption coefficient. For these reasons, there are many researches on other materials in order to replace the silicon. Among these materials, the Semiconductors groups II-VI are the best candidates. The use of thin films semiconductor has generated great interest in the development of various applications in optoelectronic and electronic devices $[1,2]$. The importance of technology-based thin film devices is mainly due to their low costs of production. The $\mathrm{Cd} \mathrm{Zn}_{1-\mathrm{x}} \mathrm{S}$ is a group II-VI important semiconductor material $[3,4], \mathrm{Cd}_{x} \mathrm{Zn}_{1-x} \mathrm{~S}$ alloy compounds have great value because their energy gap can be adjusted and network parameters can be modified $[5,6,7]$. $\mathrm{Cd}_{\mathrm{x}} \mathrm{Zn}_{1-\mathrm{x}} \mathrm{S}$ ternaries can form a continuous series of solid solutions. $\mathrm{CdZnS}$ thin films were deposited by a variety of techniques, for example, Chemical Bath Deposition (CBD) [8, 9], Spray Pyrolysis [10, 11], Successive Ion Layer Adsorption and Reaction (SILAR) [12], vacuum evaporation [13, 14], the method Dip Coating [15] and the screen printing technique [16]. Chemical deposition processes are the low-cost process. The Chemical Bath Deposition is an evolution of the process by controlled precipitation from solution. This process has recently been developed for the deposition of thin layers of the metal chalcogenide. CBD method attracts attention today because they do not require sophisticated and expensive equipment (vacuum systems): simple hot plates with a magnetic stirrer are required. In this work have been synthesized and studies the proprieties (optics, morphological and chemical composition) of CdZnS thin films obtained by Bain chemical deposition, to replace the CdS in the solar cell.

\section{EXPERIMENTAL}

The ion source materials for $\mathrm{Cd}^{2+}, \mathrm{Zn}^{2+}$ and $\mathrm{S}^{2-}$ were used $\mathrm{CdCl}_{2}$, $\mathrm{Zn}\left(\left(\mathrm{C}_{2} \mathrm{H}_{3} \mathrm{O}_{2}\right)_{2} .2 \mathrm{H}_{2} \mathrm{O}\right)$ and $\mathrm{NH}_{2}-\mathrm{CS}-\mathrm{NH}_{2}$, respectively. For the elaboration thin films of good quality was used the concentration of $\mathrm{CdCl}_{2}(0.7,0.5,0.1 \mathrm{M}), \mathrm{Zn}\left(\left(\mathrm{C}_{2} \mathrm{H}_{3} \mathrm{O}_{2}\right)_{2} \cdot 2 \mathrm{H}_{2} \mathrm{O}\right)(0.3,0.5,0.9 \mathrm{M})$ and $\mathrm{NH}_{2}-\mathrm{CS}-\mathrm{NH}_{2}(\mathrm{lM})$, all the solutions were prepared in distilled

Copyright: (-) The authors. This article is open access and licensed under the terms of the Creative Commons Attribution License (http://creativecommons.org/licenses/by/4.0/) which permits unrestricted, use, distribution and reproduction in any medium, or format for any purpose, even commercially provided the work is properly cited. Attribution - You must give appropriate credit, provide a link to the license, and indicate if changes were made. 
water, to obtain a homogeneous solution were agitated each of the elementary solutions sources for 5 minutes to obtain a thin films uniform. In a $100 \mathrm{ml}$ beaker were mixed with appropriate amounts of $\mathrm{CdCl}_{2}, \mathrm{Zn}\left(\left(\mathrm{C}_{2} \mathrm{H}_{3} \mathrm{O}_{2}\right)_{2} \cdot 2 \mathrm{H}_{2} \mathrm{O}\right)$ and $\mathrm{NH}_{2}-\mathrm{SH}-\mathrm{NH}_{2}$ solutions and addition of $\mathrm{NH}_{4} \mathrm{OH}$ to adjust the $\mathrm{pH}$ to 12 . The mixture was stirred a new to form a homogeneous solution. The glass substrates were placed vertically inside the beaker after cleaning using a standard process. The reaction temperature of bath and the time deposition were maintained at $80 \pm 5^{\circ} \mathrm{C}$ and 30 minutes respectively. The films were deposited with continuous stirring. To remove impurities from the surface and minimize agglomeration of the particles were made necessary cleaning of films deposited with deionized water and dried with $\mathrm{N}_{2}$ gas. As deposited, the color of $\mathrm{Cd}_{\mathrm{x}} \mathrm{Zn}_{\mathrm{l-x}} \mathrm{S}$ thin films was yellow gold. During annealing, the oven vacuum used at the temperature was $500{ }^{\circ} \mathrm{C}$ for 1 hour.

\section{Characterization}

The performance of the visible light transmittance of the sample was measured using a Shimadzu UV-1800 spectrophotometer. The surface morphology of the film was observed by scanning electron microscopy (SEM) model JEOL JSM-6610LA. The crystal structure of the samples was characterized by a Bruker X-ray diffractometer with a $\mathrm{Cu}-\mathrm{K} \alpha$ radiation wavelength $(1.54 \AA)$ and the Raman spectra were recorded with a Bruker SENTERRA R200L spectrometer.

\section{RESULTS AND DISCUSSION}

\section{Morphological Properties}

The surface of CdxZnl-xS thin films of composition $\mathrm{x}=0.7$, $0.5,0.1$, respectively, is observed by SEM is shown in Figure 1. The CdZnS layer consists of a dense layer of small crystallites and some large particles sink to the surface. These particles are most likely CdxZnl-xS colloidal particles formed on the substrate during film growth. As the composition (x) of $\mathrm{Zn}$ increases, is advantage incorporated into the CdS films. Which are indicated by XRD as well as SEM [17, 32]. The shape of the particle changes with increasing concentration of $\mathrm{Zn}$.

\section{Optical Properties}

The transmittance of $\mathrm{CdZnS}$ thin films with different concentrations is using a Spectrophotometer UV-visible (Shimadzu UV-1800). We observe that the transmittance of our samples is varied between 60 and $80 \%$ in visible region this variation due to the decrease in Zinc concentration. Whereas in the region $<450 \mathrm{~nm}$ fundamental absorption therefore, our thin films possess transparency performance in the 450-800 $\mathrm{nm}$ region, the latter gives them great importance in solar cells as a buffer layer.

The optical gap energy Eg was obtained by extrapolation of the linear part of $(\alpha h v)^{2}$ on the axis of $(h v)$ to $\alpha=0$, according to the following equation [18]:

$$
\alpha=\mathrm{A}(\mathrm{h} v-\mathrm{Eg})^{\mathrm{n}}
$$

With $A$ is the edge parameter and $n=1 / 2$ for direct gap material, $h v$ is the photon energy, Eg is the band gap. Values of optical band

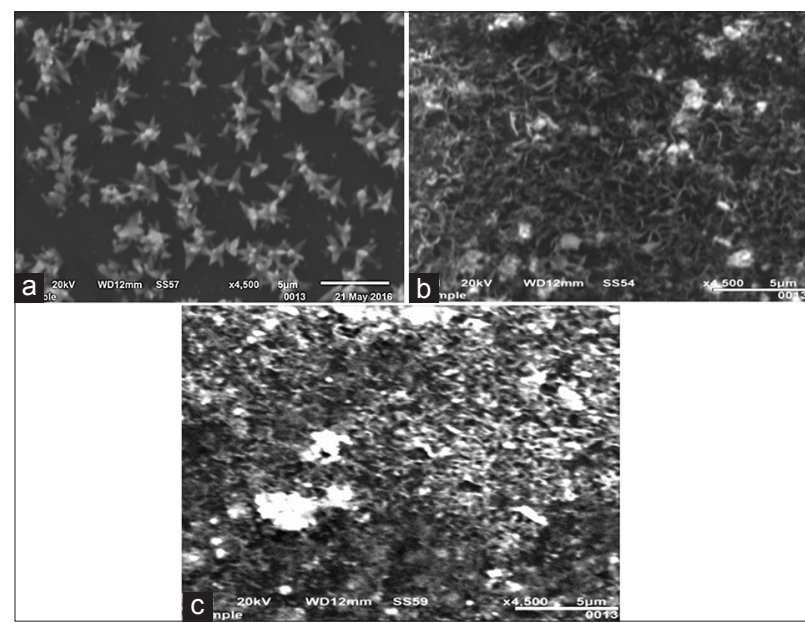

Figure 1: Typical SEM images of nanostructured $C d_{x} Z n_{1-x} S$ thin films $\left(\mathrm{a}=\mathrm{Cd}_{0.1} \mathrm{Zn}_{0.9} \mathrm{~S}, \mathrm{~b}=\mathrm{Cd}_{0.5} \mathrm{Zn}_{0.5} \mathrm{~S}, \mathrm{c}=\mathrm{Cd}_{0.7} \mathrm{Zn}_{0.3} \mathrm{~S}\right)$ annealed at $500{ }^{\circ} \mathrm{C}$

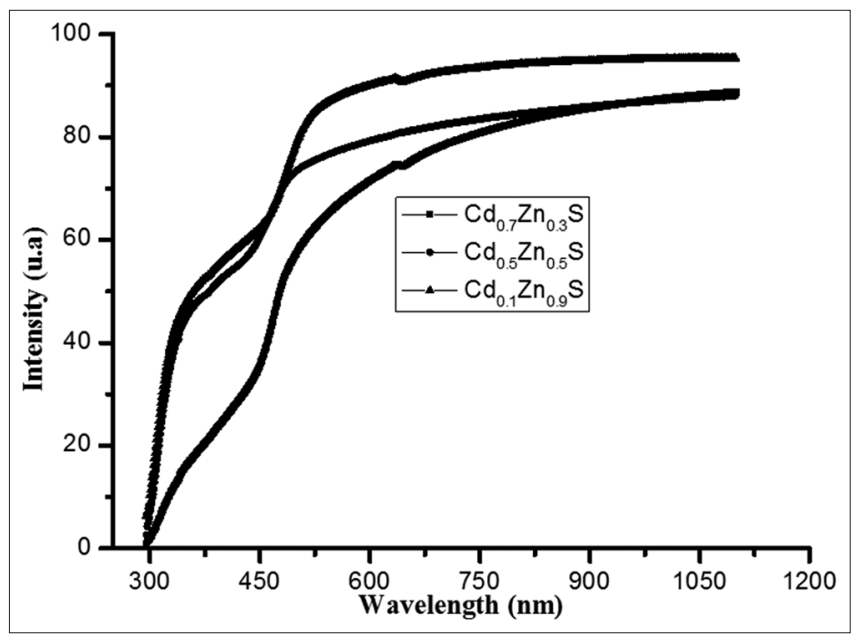

Figure 2: Transmission spectra of $\mathrm{Cd}_{x} \mathrm{Zn}_{1-x} \mathrm{~S}$ thin films.

gap Eg of thin films $\left(\mathrm{Cd}_{0.7} \mathrm{Zn}_{0.3} \mathrm{~S}, \mathrm{Cd}_{0.5} \mathrm{Zn}_{0.5} \mathrm{~S}\right.$ and $\left.\mathrm{Cd}_{0.1} \mathrm{Zn}_{0.9} \mathrm{~S}\right)$ are $(3.5,3.61$ and $3.8 \mathrm{eV})$ respectively, we find that the gap energies of our thin layers are closer to that of $\mathrm{ZnS}[19,20]$.

\section{Structural Proprieties}

X-ray diffraction (XRD) spectra provide information on the composition and nature of the structure of a thin film. These X-ray diffraction patterns confirm the formation of the ternary system $\mathrm{Cd}_{\mathrm{x}} \mathrm{Zn}_{1-\mathrm{x}} \mathrm{S}$ with $\mathrm{x}=(0.1,0.5,0.7)$ are present in Figure 4. The peaks: (100), (002), (101), (110), (103), (200) and (201) correspond to the hexagonal structure of the thin films of $\mathrm{Cd}_{07} \mathrm{Zn}_{0.3} \mathrm{~S}$ and $\mathrm{Cd}_{0.5} \mathrm{Zn}_{0.5} \mathrm{~S}$. The peak (002) is the most intense for $\mathrm{Cd}_{0.7} \mathrm{Zn}_{0.3} \mathrm{~S}$ and $\mathrm{Cd}_{0.5} \mathrm{Zn}_{0.5} \mathrm{~S}$. But for $\mathrm{Cd}_{0.1} \mathrm{Zn}_{0.9} \mathrm{~S}$, the peaks are (111), (200), (210), (211), (300), (222), (321) and (400), the most intense peak is (200), correspond to the cubic structure. For determinations the values of the interplanar distance $d$ experimental for the different compositions of the system $\mathrm{Cd}_{\mathrm{x}} \mathrm{Zn}_{1-\mathrm{x}} \mathrm{S}$ was used the Bragg relation [21] taking the value $\theta$ of the peak position of the XRD diagram. $\mathrm{d}_{\text {exp }}$ values 200B200B were compared with $\mathrm{d}_{\text {(ASTM) }}$ values; Both values $200 \mathrm{~B} 200 \mathrm{~B}$ are in good agreement; the values 200B200B of the interplanar 


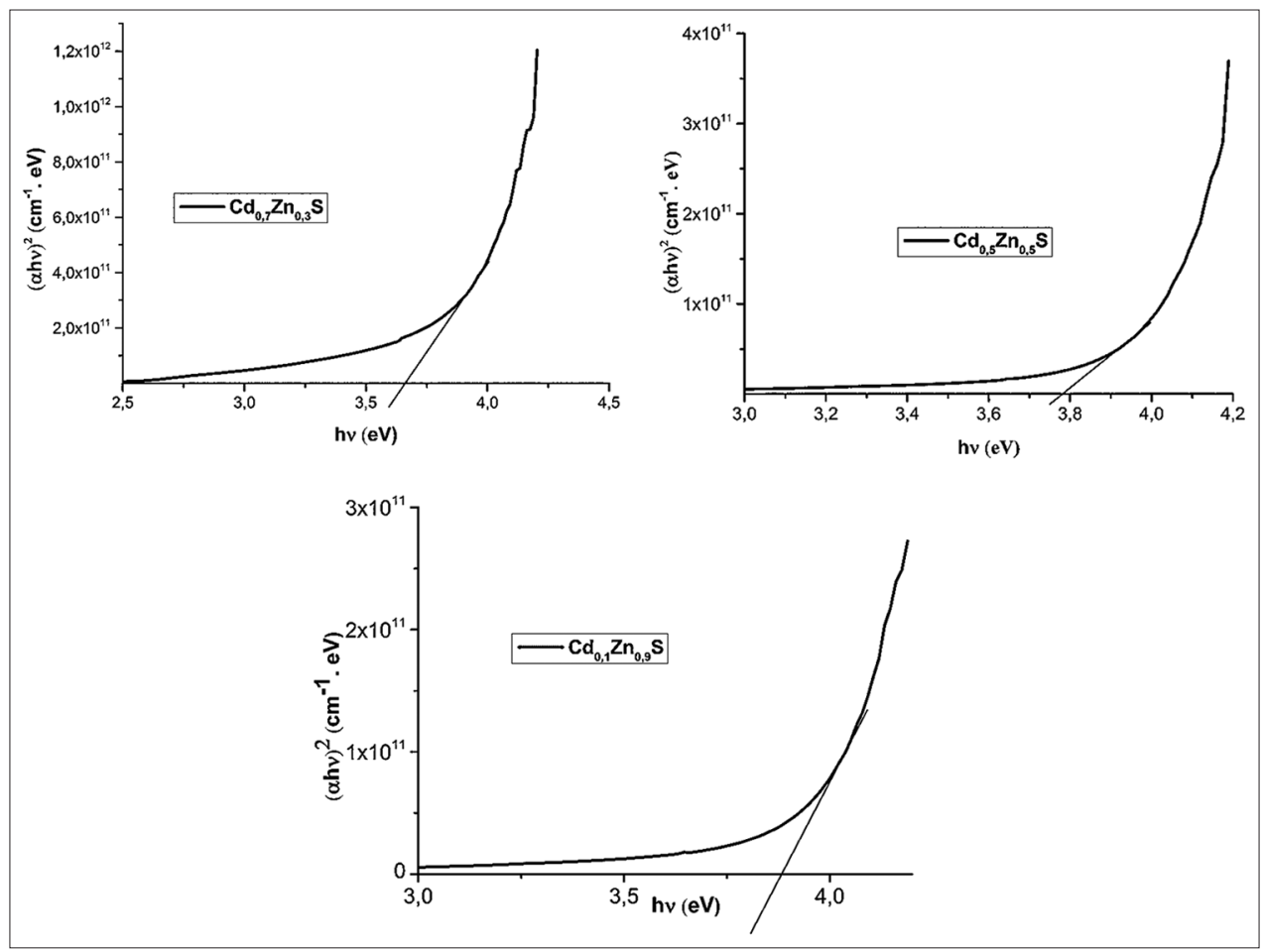

Figure 3: Extrapolations of $E_{g}$ for $\mathrm{Cd}_{x} \mathrm{Zn}_{1-x} \mathrm{~S}$ thin films

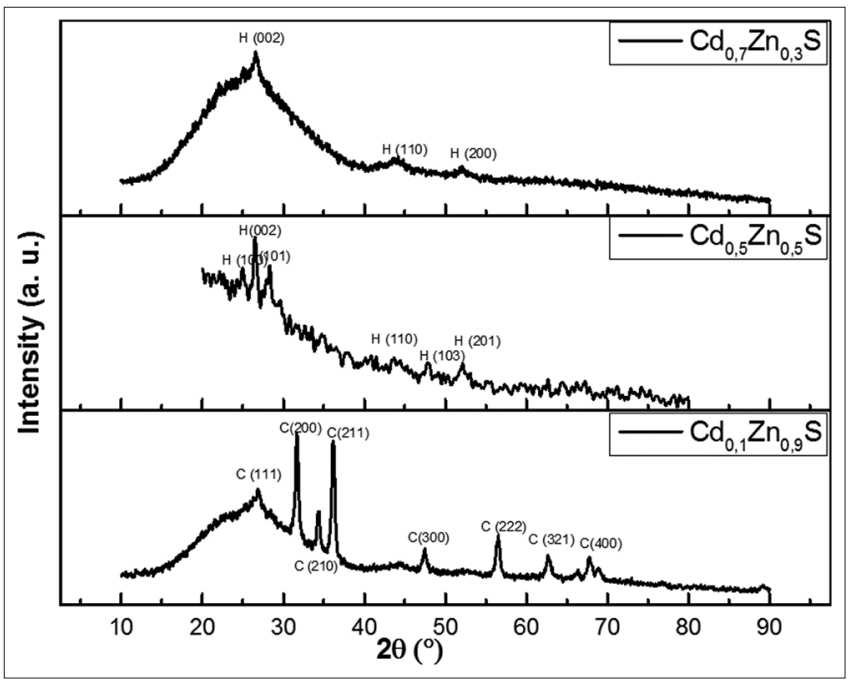

Figure 4: XRD pattern of $\mathrm{Cd}_{\mathrm{x}} \mathrm{Zn}_{1-\mathrm{x}} \mathrm{S}$ thin films

distance of the ternary alloy $\mathrm{Cd}_{\mathrm{x}} \mathrm{Zn}_{1-\mathrm{x}} \mathrm{S}$ will be linear as a function of the $\mathrm{x}$ concentration, as indicated in the TAB. 1. [22]

$$
\mathrm{d}=(\lambda / 2 \sin \theta)
$$

The $\mathrm{D}$ average size of the crystallites of $\mathrm{CdZnS}$ estimated according by the formula of Debye-Scherer's [23].

$$
D=0.9 \lambda(\square(2 \theta) \cos \theta)
$$

Where $\mathrm{D}$ is the crystallite average size, $\lambda=0.154 \mathrm{~nm}$ the mean wavelength of $\mathrm{Cu} \mathrm{K \alpha}$ radiation and $\beta=(\Delta 2 \theta)$ is the full-width half maximum (FWHM) of Bragg peak observed at Bragg angle $\theta$ (rad), $\mathrm{K}=0.9$, the values of $\mathrm{D}$ obtained were presented in Table $\mathrm{l}$.

The dislocation density $(\delta)$ is the number of crystallites per unit area $(\mathrm{N})$ and the strain $(\varepsilon)$ of the films are determined by relations [24].

$$
\begin{aligned}
& \delta=1 / D^{2} \\
& \varepsilon=\beta \cos \theta / 4
\end{aligned}
$$

The size values of the grains, the dislocation and the deformation of the crystallites of the thin films CdxZnl-xs deposited at a temperature of $80 \pm 5^{\circ} \mathrm{C}$ and annealing at $500^{\circ} \mathrm{C}$ are presented in Table 1. In the table, we see as the size of the crystallites increases with the increase of zinc compositions ( $\mathrm{x}$ ), a maximum value of the size of the crystallites corresponds to a minimum value of the deformation. On the other hand, the density of the dislocations decreased with the increase of the zinc compositions (x). CdxZnl-xS thin films with a lower dislocation and deformation density improve the stoichiometry of the films, resulting in the volumetric expansion of the thin films [8].

The values of the lattice parameter were calculated using the formula (6) and (7):

$$
\begin{aligned}
& \frac{1}{d^{2}}=\frac{4}{3} \frac{\left(h^{2}+h k+k^{2}\right)}{a^{2}}+\frac{l^{2}}{c^{2}} \\
& \frac{1}{d^{2}}=\frac{\left(h^{2}+k^{2}+l^{2}\right)}{a^{2}}
\end{aligned}
$$


Table 1: XRD results of $\mathrm{CdZnS}$ thin films

\begin{tabular}{|c|c|c|c|c|c|c|c|}
\hline & (hkl) & $d_{\text {exp }}$ & $d_{\text {(ASTM) }}$ & $D(n m)$ & Lattice parameter- $\AA$ & $\delta$ & $\varepsilon$ \\
\hline $\mathrm{Cd}_{0,7} \mathrm{Zn}_{0.3} \mathrm{~S}$ & (002) & 3.35 & 3.39 & 9.95 & $c=6.62, a=4.08$ & $1,00 E+16$ & 0,215 \\
\hline $\mathrm{Cd}_{0.5}^{0.1} \mathrm{Zn}_{0.5}^{0.3} \mathrm{~S}$ & $(002)$ & 3.35 & 3.35 & 20.66 & $c=6.42, a=3.95$ & $2,39 E+15$ & 0,103 \\
\hline $\mathrm{Cd}_{0.1}^{0.5} \mathrm{Zn}_{0.9}^{0.5} \mathrm{~S}$ & $(200)$ & 2.82 & 2.76 & 25.82 & $a=5.73$ & $1,50 E+16$ & 0,083 \\
\hline
\end{tabular}

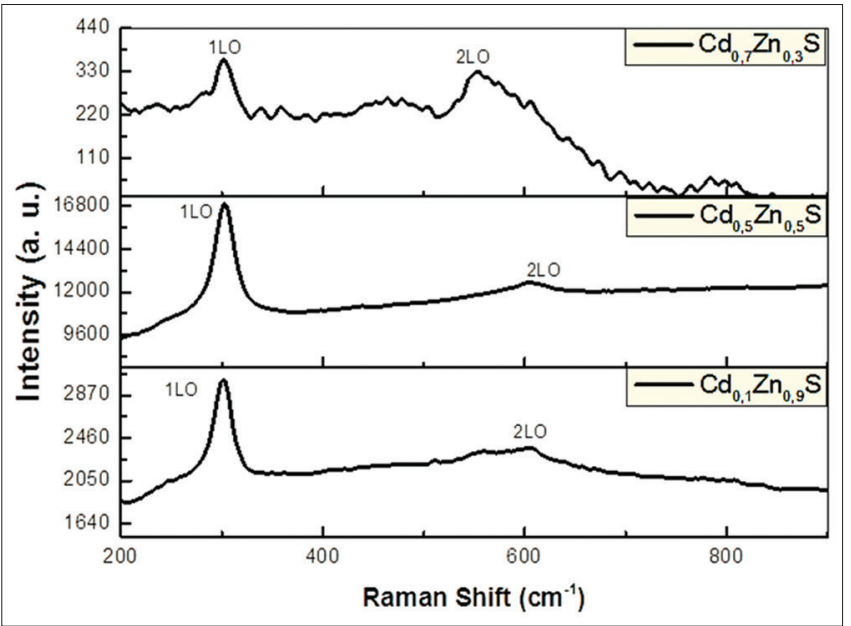

Figure 5: Raman spectra of $\mathrm{Cd}_{x} \mathrm{Zn}_{1-x} \mathrm{~S}$ thin films

Moreover, the obtained values are compiled in Table 1 [25], the lattice parameter is decreased when the zinc concentration increases, when the zinc concentration is greater than $0.5 \mathrm{M}$ the crystal structure changes from hexagonal to cubic.

\section{Raman Analysis}

Raman spectroscopy is one of the essential tools for the structural characterization of materials. Figure 5 shows Raman spectra at room temperature in the visible region 200 and $800 \mathrm{~cm} \mathrm{-1.} \mathrm{The} \mathrm{position} \mathrm{of} \mathrm{the} \mathrm{spectral} \mathrm{peak} \mathrm{and} \mathrm{the} \mathrm{spectral}$ width of the Raman spectra give information on the quality of the crystallinity of the film [30]. It has been noted that there are two large, well resolved asymmetric peaks corresponding to the $1 \mathrm{LO}$ and 2LO phonon modes in the spectrum $[26,27]$. The peak position of the LO mode varies with the composition

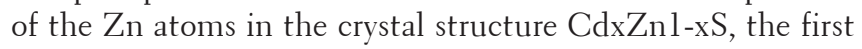
peaks were observed at $301.5 \mathrm{~cm}-1,302.5 \mathrm{~cm}-1$ and $303 \mathrm{~cm}-1$. Peaks of $590.4 \mathrm{~cm}-1$ and $681.3 \mathrm{~cm}-1$ can respectively affect the second modified harmonic of the $\mathrm{CdZnS}$ phonon. The existence of $1 \mathrm{LO}$ and 2LO phonon modes confirms the presence of a highly crystalline material. Ozer et al. Show that the intensity of Raman peaks changes because of the damage and disorder induced by Zn incorporation [29, 31] RS. Castillo et al showed that FWHM increases inversely with particle size [28]. The diffusion of $\mathrm{Zn}$ into the crystalline structure also resulted in a more asymmetrical line shape towards a higher energy side.

\section{CONCLUSIONS}

The CdZnS thin films are produced by the chemical bath deposition technique. The synthesis was easy to achieve on large-area glass substrates. The SEM characterization study shows that the morphology of the surface is changed depending on the concentration of zinc. The transmittance is about 60 to $80 \%$ and the energy of the range is changed from 3.5 to $3.8 \mathrm{eV}$. The crystalline structure is hexagonal for $\left(\mathrm{Cd}_{0.7} \mathrm{Zn}_{0.3} \mathrm{~S}\right.$ and $\mathrm{Cd}_{0.5} \mathrm{Zn}_{05} \mathrm{~S}$ ) and cubic for $\mathrm{Cd}_{01} \mathrm{Zn}_{00} \mathrm{~S}$. and the grain size is between 9.95 and $25 \mathrm{~nm}$.

\section{REFERENCES}

1. T. Gruszecki, B. Holmstrom, Sol. Energy Mater. Sol. Cells31 (1993) 227-234.

2. D. Xia, T. Caijuan, T. Rongzne, L. Wei, F. Lianghuan, Z. Jingquan, W. Lili, L. Zhi, J. Semicond.32 (2011) 22003.

3. T.D. Dzhafarov, F. Ongul, I. Karabay, J. Phys. D Appl. Phys. 39 (2006) 3221.

4. T. Prem Kumar, S. Sarvana Kumar, K. Sankaranarayanan, Appl. Surf Sci. 257(2011) 1923-1927.

5. D. Xia, T. Caijuan, T. Rongzhe, L. Wei, F. Lianghuan, Z. Jingquan, W. Lili, L. Zhi, J. Semicond. 32(2011)1 - 4022003

6. Ng. Gaewdang, T. Gaewdang, Materials Letters 59 (2005) 3577 - 3584

7. A. Mukherjee, M. Fu, P. Mitra, Journal of Physics and Chemistry of Solids 82(2015)50-55.

8. R. Mariappan, M. Ragavendar, V. Ponnuswamy, J. Alloys Compd. $509(2011) 7337-7343$.

9. P.B. Bagdare, S.B. Patil, A.K. Singh, J. Alloys Compd. 506(2010) 120-124.

10. Y. Ravi Prakash, K.V. Bangera, G.K. Shivakumar, Growth, Appl. Phys. 10 (2010) 193-198.

11. M. Glatettin Baykul, Nilgun orhan, Thin Solid Films 518 (2010) 1925-1928.

12. G. Laukaitish, S. Lindroos, S. Tamulevicius, M. Leskela, M. Rackaitis, Appl. Surf. Sci. 161 (2000) 396-405.

13. D. Patidar, N.S. Saxena, T.P. Sharma, J. Mod. Opt. 55 (2008) 79-88.

14. P. Kumar, A. Misra, D. Kumar, N. Dhama, T.P. Sharma, P.N. Dixit, Opt. Mater. 27 (2004) 261-264.

15. M. Abdel Rafea, A.A.M. Farag, N. Roushdy, J. Alloys Compd. 485 (2009) 660-666.

16. V. Kumar, S.K. Sharma, D.K. Dwivedi, J. Alloys Compd. 512 (2012) 351-354.

17. S.V. Borse, S.D. Chavhan, Rampha Sharma, Journal of Alloys and Compounds 436 (2007) 407-414

18. Y. Bakha, K.M. Bendimerad, and S. Hamzaoui, Eur. Phys. J. Appl. Phys. 55, 30103 (2011)

19. K. Nagamani, N. Revathi, P. Prathap, Y. Lingappa, K.T. Ramakrishna Reddy, Current Applied Physics 12 (2012) 380-384

20. T. Ben Nasr, N. Kamoun, M. Kanzari, R. Bennaceur, Thin Solid Films 500 (2006) $4-8$

21. Metin, H., Ari, M., Erat, S., Durmuş, S., Bozoklu, M., \& Braun, A. Journal of Materials Research, 25 (1), 189-196 (2010).

22. BD Cullity, Elements of X-ray Diffraction (Addison Wesley, London, 1959).

23. D. PATIDAR, N. S. SAXENA, T. P. SHARMA, Journal of Modern Optics, Vol. 55, No. 1, January 10, 2008, 79-88

24. Urvashi Verma, Vikas Thakur, Poolla Rajaram, and A. K. Shrivastava, Electron. Mater Lett, Vol. 11, No. 1 (2015), pp. 46-54

25. Allah Bakhsh, Iftikhar Hussain Gul, Asghari Maqsood, Shang-Hsuan Wu, Ching-Hsiang Chan, Yia Chung Chang, Materials Science Forum 886 (2017) pp 24-31.

26. G. Selvan, M.P. Abubacker, A.R. Balu, Optik 127 (2016) 4943-4947.

27. L.V.Titova, T. B. Hoang, A. Mishra, L. M. Smith, H. E. Jackson, K.Y. Lee, H. Rho, J. M. Yarrison-Rice, Y.J. Choi, K. J. Choi, J.G. Park. Appl. Phys. Lett. 92 (2008).

28. R.S.Castillo-Ojeda, J. Díaz-Reyes, R. Sanchez-Espíndola, M Galvan-Arellano, O. Zaca-Moran. Current Applied Physics 15 (2015). 
Zellagui, et al.

29. A. BAKHSH, I. H. GUL, A. MAQSOOD, C. H. CHAN, S. H. WU, Y. C. CHANG, Chalcogenide Letters Vol. 13, No. 10, October 2016, p.443 - 450.

30. Tuley ozer, Sabita Aksay, Salih Kose, Master. Sci. Semicond. Proe. 13(2010) 325-328.

31. V. Narasimman, V. S. Nagarethinam, K. Usharani and A. R. Balu,
International Journal of Thin Films Science and Technology, 5, No. 1(2016), 17-24.

32. Chavhan SD, Senthilarasu S, Lee SH. Annealing effect on the structural and optical properties of a Cd1- xZnxS thin film for photovoltaic applications. Applied Surface Science. 2008 May 30;254(15):4539-45. 